\title{
Ageing and growth of the endangered midwife toad Alytes muletensis
}

\author{
Samuel Pinya ${ }^{1, *}$, Valentín Pérez-Mellado ${ }^{2}$ \\ ${ }^{1}$ Herpetological Research and Conservation Centre, Associació per a l'Estudi de la Natura, Balearic Islands, Spain \\ ${ }^{2}$ Department of Animal Biology, Universidad de Salamanca, Spain
}

\begin{abstract}
A better understanding of the demography of endangered amphibians is important for the development of suitable management and recovery plans, and for building population viability models. Our work presents, for the first time, growth curves and measurements of mean longevity, growth rates and age at maturity for the Vulnerable midwife toad Alytes muletensis. Von Bertalanffy growth models were used to estimate longevity and growth rate parameters. Females had a mean $( \pm \mathrm{SD})$ longevity of $4.70 \pm 0.19 \mathrm{yr}$, significantly higher than that of males $(3.24 \pm 0.10 \mathrm{yr})$. The maximum estimated longevity was $18 \mathrm{yr}$ for both males and females. The age distribution indicated that males reached sexual maturity at the age of $1 \mathrm{yr}$, and most females at $2 \mathrm{yr}$. There were significant differences in growth rate between sexes, with higher values in females during the first $4 \mathrm{yr}$ of life, and similar values in both sexes thereafter. These life-history traits were compared with equivalent measures in the closely related amphibian genera Bombina and Discoglossus.
\end{abstract}

KEY WORDS: Alytes muletensis $\cdot$ Longevity $\cdot$ Growth rate $\cdot$ Age structure $\cdot$ Balearic Islands

\section{INTRODUCTION}

Researchers and wildlife managers require basic biological information about wildlife populations to understand and monitor their changes over time (Cheong et al. 2007). The ability to accurately estimate the ages of animals is also essential for the acquisition of information about the demographic characteristics of a population, including mortality, longevity and other variables (Halliday \& Verrell 1988).

The Mallorcan midwife toad Alytes muletensis is an endemic and endangered species of northwest Mallorca (Balearic Islands, Spain) (IUCN 2013). Its current distribution range is limited to a small area of the Tramuntana mountain range (Román 2002), where it inhabits streams with vertical side walls and beds with a stepped profile (Alcover et al. 1984). No information about the age structure and growth of this species has been published. Skeletochronology is a reliable and very useful technique to estimate the age of amphibians and reptiles (Castanet \& Smirina 1990, Castanet 2002), but this method is invasive and not appropriate for endangered species with small population sizes, such as A. muletensis (Arnold 2003). The estimation of age by the analysis of size class distribution (e.g. snout-vent length [SVL] measurements) or mark-recapture records, although extremely laborious (Halliday \& Verrell 1988), may be the only way to study population demography in this endangered amphibian species.

Thus, growth models are useful tools for studying life histories because they allow the quantification of important demographical parameters such as age at maturity or differential growth patterns among age and sex groups (Frazer et al. 1990). They have been widely employed for amphibians (Arntzen 2000, Guarino et al. 2003, Jakob et al. 2003, Cheong et al. 2007, Matthews \& Miaud 2007), but rarely in the case of closely related species from the family Discoglossi- 
dae (Plytycz \& Bigaj 1984, Cogalniceanu \& Miaud 2003), and never for species from the family Alytidae.

Maximum longevity in wild populations of continental Alytes species is poorly known (Table 1). For the insular endemic species A. muletensis, captive individuals are known to have reached at least 7 yr of age (Bush 1993, Román \& Mayol 1997). This information still needs to be investigated in wild populations of $A$. muletensis. A better understanding of the demography of wild populations, including information on growth rates and mean longevity, could be useful in the development of management and recovery plans, as well as in constructing population viability models (Cheong et al. 2007).

\section{MATERIALS AND METHODS}

To estimate the age of Alytes muletensis individuals, populations from 17 localities were studied from 2005 to 2012. Adult toads were captured and sexed, measuring their SVL to the nearest $0.01 \mathrm{~mm}$. A digital picture of their dorsal surface was taken to identify individuals in future re-captures, following the methodology proposed by Pinya \& Pérez-Mellado (2009). Using recapture records, we established the age of a group of males and females, which was correlated to their SVL. Thus, those individuals that were captured as juveniles (post-metamorphic) were assigned an age of $1 \mathrm{yr}$, and when the same individual was captured several years later, the appropriate number of years was added to its age. With the SVL and age data, growth curves were constructed for both sexes, based on the nonlinear von Bertalanffy equation (Fabens 1965): $L t=a\left(1-b \mathrm{e}^{-k t}\right)$, where $L_{t}$ is the SVL at a specific age, $t$ is the age in years, $a$ is the asymptotic or maximum SVL, $b$ is the SVL at metamorphosis, e is the natural logarithmic base and $k$ is the growth constant.

Von Bertalanffy growth functions were calculated separately for males and females, with juveniles of known sex included in both estimates. Without the inclusion of juveniles, the von Bertalanffy model underestimates the parameters $a$ and $k$, resulting in incorrect age estimates (Spencer 2002, Martins \& Souza 2008). After obtaining the parameters $a, b$ and $k$, the parameter $t$ was estimated based on the original von Bertalanffy equation, resulting in the species' growth curve estimates (Zug et al. 1997, Spencer 2002).
Once the equations were constructed, they were used to estimate the age of the individuals of unknown age. Then, with the pooled data from both sexes (those individuals of known age and those with an estimated age), the final growth curves of Alytes muletensis were built.

Age data were grouped into 14 age classes: 1, 2, 3, ... 12 yr, 13-14 yr and 15-18 yr. Age-specific growth rate was calculated with the equation: $\mathrm{dSVL} / \mathrm{d} t=$ $k\left(\mathrm{SVL}_{\max }-\mathrm{SVL}_{t}\right)$, which gives the maximal growth rate when $\mathrm{SVL}_{t}$ is minimal (Ma \& Lu 2009).

Differences in age, body size and growth rate between sexes were compared with Kruskal-Wallis tests or one-way ANOVA. G-tests were used to compare age structure between sexes. All probabilities were 2-tailed, and the significance level was set at $\mathrm{p}=0.05$. The statistical analyses were carried out in $\mathrm{R}$.

\section{RESULTS}

Ages of 422 toads (175 females and 247 males) from a total of 999 sampled toads were estimated using capture-recapture records. The ages of the remaining 577 toads (173 females and 404 males) were estimated using von Bertalanffy growth curves. SVL and growth rates of males and females showed heterogeneous variances (SVL, Fligner-Killeen test, $\chi^{2}=45.88, \mathrm{p}<0.001$; growth rates, $\chi^{2}=113.51, \mathrm{p}<$ 0.001), even after log transformation. Thus, we employed a Kruskal-Wallis test to compare sexes.

Females had a mean longevity of $4.70 \pm 0.19 \mathrm{yr}$ (range 1 to $18 \mathrm{yr}, \mathrm{n}=347$ ), which was significantly higher (1-way ANOVA of log-transformed values of ages, $F_{1,995}=82.13$, p $<0.0001$; Table 2, Fig. 1) than the longevity of males $(3.24 \pm 0.10 \mathrm{yr}$, range 1 to $18 \mathrm{yr}$, $\mathrm{n}=650$ ), whilst the maximum longevity for both 

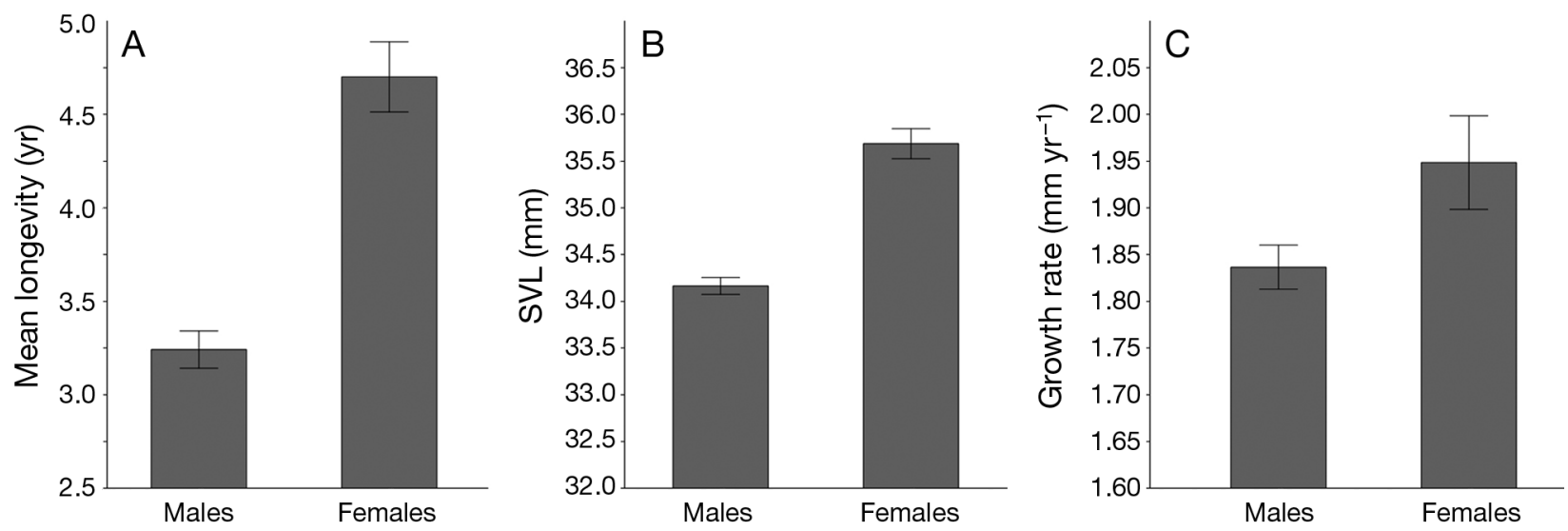

Fig. 1. Alytes muletensis. (A) Mean longevity (yr), (B) body size (snout-vent length [SVL], mm) and (C) growth rate (mm $\mathrm{yr}^{-1}$ ) of female and male toads in the present study. Error bars indicate $\pm \mathrm{SE}$

Table 2. Statistical parameters of body length, age and growth rate, and results of Kruskall-Wallis or ANOVA tests for differences between sexes. SVL: snout-vent length. Gaps indicate not applicable

\begin{tabular}{|c|c|c|c|c|c|c|}
\hline & \multicolumn{2}{|c|}{$\begin{array}{l}\text { Body length } \\
\text { (SVL, mm) }\end{array}$} & \multicolumn{2}{|c|}{$\begin{array}{c}\text { Age }- \\
(\mathrm{yr})\end{array}$} & \multicolumn{2}{|c|}{$\begin{array}{c}\text { Growth rate } \\
\left(\mathrm{mm} \mathrm{yr}^{-1}\right)\end{array}$} \\
\hline & Males & Females & Males & Females & Males & Females \\
\hline $\mathrm{n}$ & 651 & 348 & 650 & 347 & 651 & 348 \\
\hline Minimum & 28.00 & 30.53 & 1 & 1 & 0.01 & 0.01 \\
\hline Maximum & 41.18 & 41.92 & 18 & 18 & 3.44 & 3.55 \\
\hline Mean & 34.16 & 35.69 & 3.24 & 4.70 & 1.84 & 1.95 \\
\hline SE & 0.06 & 0.16 & 0.10 & 0.19 & 1.02 & 0.05 \\
\hline$\chi^{2}$ & 56.35 & & & & 4.91 & \\
\hline ANOVA & & & 82.13 & & & \\
\hline $\mathrm{p}$ & $6.04 \times 10^{-1}$ & & 0.0001 & & 0.026 & \\
\hline
\end{tabular}

males and females was 18 yr (Fig. 2). In addition, there was a significant difference in age structure between the sexes ( $G$-test, $G=125.88 \mathrm{p}<0.001)$. Statistical differences were observed between sexes in the 1, 2, 3 and 15 to $18 \mathrm{yr}$ age classes, showing that there were more young males than females, and

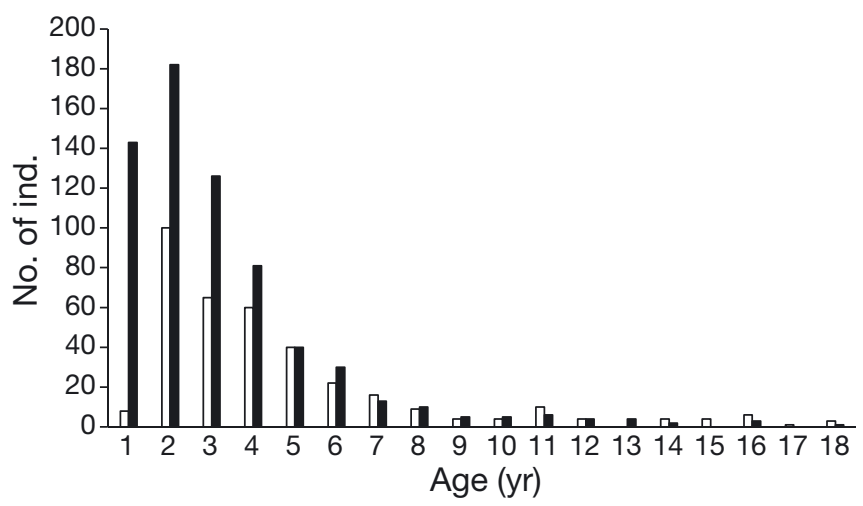

Fig. 2. Alytes muletensis. Age distribution (yr) of males (black) and females (white) (total $\mathrm{n}=999$ ) more females reaching ages of $>14 \mathrm{yr}$ than males. The distribution of different age classes indicated that males reached sexual maturity at $1 \mathrm{yr}$ old, and most females at $2 \mathrm{yr}$.

Body length (SVL) was significantly larger in females than in males (males, $34.16 \pm 0.09 \mathrm{~mm}$, range $28-41.18 \mathrm{~mm}$, $\mathrm{n}=651$; females, $35.69 \pm 0.16 \mathrm{~mm}$, range 30.53-41.92 $\mathrm{mm}, \mathrm{n}=348$; Kruskal-Wallis test, $\chi^{2}=56.35, \mathrm{p}<$ 0.001, (see Table 2, Fig. 1 and similar results in Pinya \& Pérez-Mellado, 2009).

The von Bertalanffy growth curves (Fig. 3) indicated small differences in body sizes between males and females at all ages. The results showed that females had asymptotic body size values $(41.96 \mathrm{~mm})$ similar to those of males, but a higher growth coefficient $k$ (0.31) than males (41.22 $\mathrm{mm}$ and 0.26 , respectively), though this was not statistically significant $\left(\chi^{2}{ }_{1}=\right.$ $1.299, \mathrm{p}=0.2543)$. Growth rate gradually decreased with increasing age. There were significant differences in growth rates between sexes (males, $1.84 \pm$ $0.02 \mathrm{~mm} \mathrm{yr}^{-1}$, range $0.1-3.44 \mathrm{~mm} \mathrm{yr}^{-1}, \mathrm{n}=651$; females, $1.95 \pm 0.05 \mathrm{~mm} \mathrm{yr}^{-1}$, range $0.01-3.55 \mathrm{~mm}$ $\mathrm{yr}^{-1}, \mathrm{n}=348$; Kruskal-Wallis test, $\chi^{2}=4.91, \mathrm{p}=0.026$ ), with higher values in females during the first $4 \mathrm{yr}$ of life and similar values for males and females thereafter (Fig. 4).

\section{DISCUSSION}

Primary demographic factors affecting population dynamics include social structure and life history variations (Lande 1988). The present study focused 

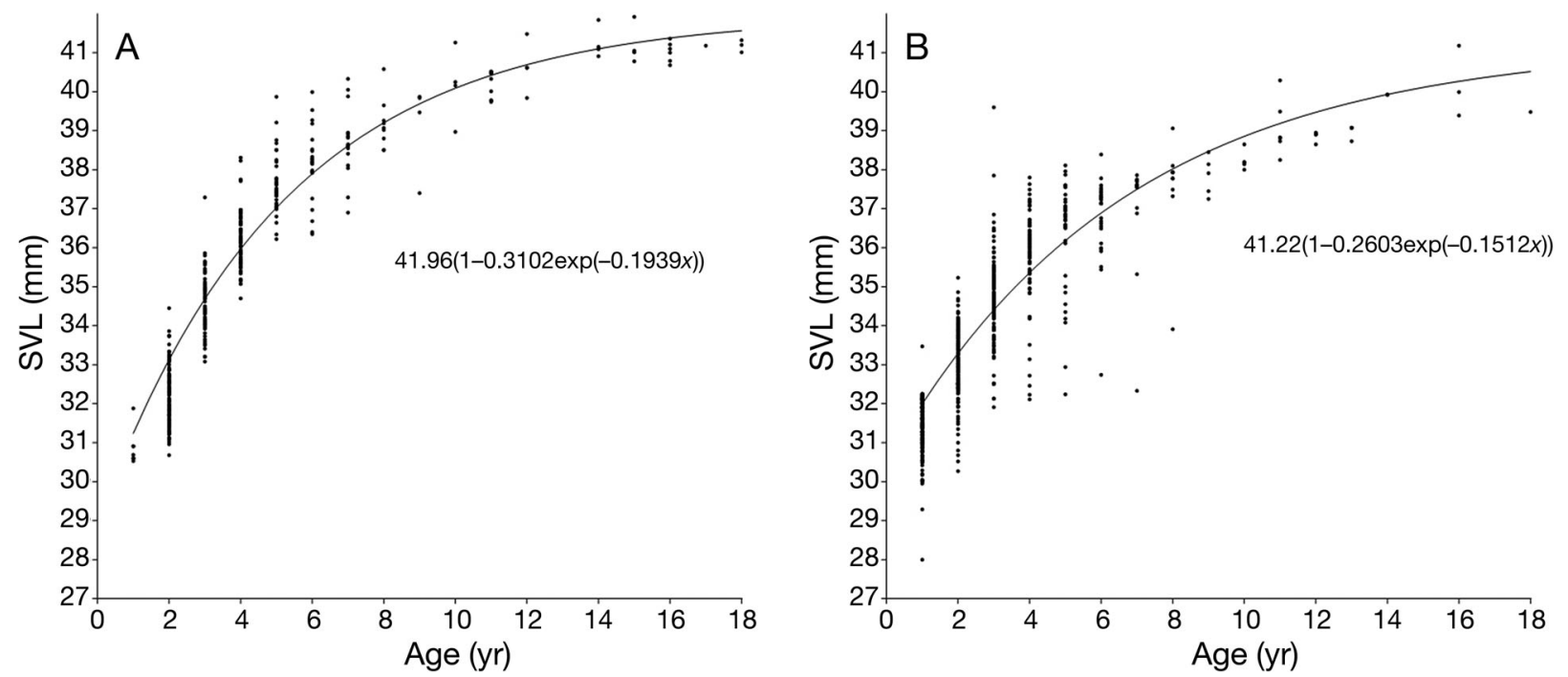

Fig. 3. Alytes muletensis. Growth curves fitted to the von Bertalanffy growth model (black line), with body size (snout-vent length [SVL], in $\mathrm{mm}$ ) and age data (yr) for (A) female and (B) male toads

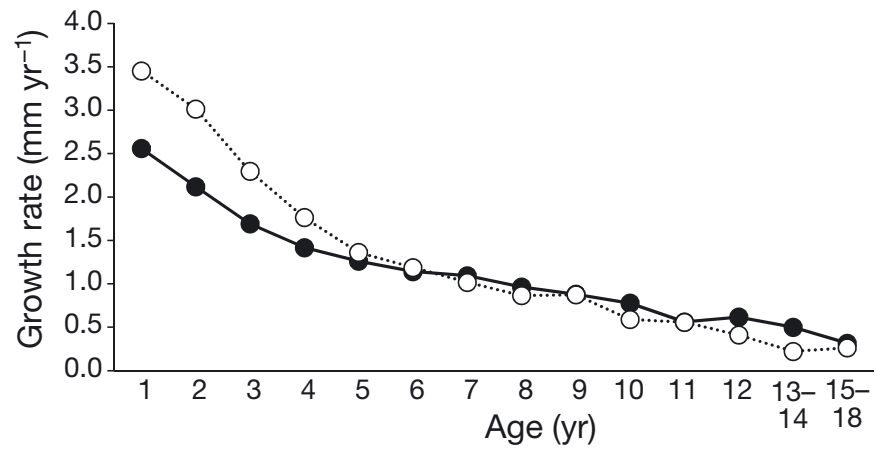

Fig. 4. Alytes muletensis. Growth rate of males (๑) and females (O) at all age stages

on basic demographical parameters such as maximum and mean longevity, growth curves, growth rates and age at maturity in wild populations of Alytes muletensis.

As in several amphibians, our data showed a positive correlation between body size (SVL) and age (Miaud et al. 1999, Yilmaz et al. 2005, Ma \& Lu 2009). We observed differences in mean longevity between sexes, biased to older females, whilst the maximum longevity was similar between the sexes. The observed mean longevity was higher when compared with that of female Alytes obstetricans and A. cisternasii (3.68 and $3.15 \mathrm{yr}$, respectively; Márquez et al. 1997), which also have a higher mean longevity than males (2.34 and $2.43 \mathrm{yr}$, respectively; Márquez et al. 1997). In general, most studies of amphibians have established that when there are differences in longevity between sexes, females live longer than males (see Cherry \& Francillon-Vieillot 1992). Other closely related species, such as Discoglossus galganoi, have similar values of mean longevity $\left(4 \mathrm{yr}_{\text {; }}\right.$ Esteban et al. 1998).

In Alytes muletensis, age at maturity varies between 1 and $2 \mathrm{yr}$, and both sexes are potentially able to reproduce in the first breeding season after metamorphosis, as in other anuran species (Guarino et al. 2003). Sexual maturity is delayed in a closely related species Discoglossus pictus (4 yr; Knoepffler 1962).

The maximum longevity recorded was $18 \mathrm{yr}$ in both sexes, but this value should be considered exceptional, because most of the captured individuals ( $90 \%$ ) were no more than 6 (males) or 9 yr old (females). In fact, this maximum value is the highest longevity ever recorded for the genus Alytes (Böllet et al. 1997, Márquez et al. 1997, González-Miras et al. 2012), but is similar to the values recorded in the related genus Bombina, with a maximum longevity of 20 yr (Pytycz \& Bigaj 1984).

Greater longevity values for females have previously been reported for some species of anurans (Cherry \& Francillon-Vieillot 1992, Leclair \& Laurin 1996, Guarino et al. 2011), and this result is generally interpreted as the consequence of a delayed sexual maturity (Kyriakopoulou-Sklavounou et al. 2008) or a lower predation pressure on females (Cherry \& Francillon-Vieillot 1992). In the case of Alytes muletensis, the first interpretation is convincing, because age at maturity is higher in females than in males. The assumption that adult males of $A$. muletensis should have a higher mortality due to predation is not yet verified. 
Growth of amphibians fits the von Bertalanffy model acceptably well, indicating that age and growth rate operate additively to determine the body size of individual amphibians (Ma \& Lu 2009). Sexual size dimorphism depends on the relative importance of age and growth rate parameters in the 2 sexes (Ma \& Lu 2009). In Alytes muletensis, females and males gradually attained the estimated asymptotic SVL. Females showed a higher growth rate and a greater average age than males, but a similar lifespan. A combination of these variables is frequently related to delayed reproduction of females (Halliday \& Tejedo 1995, Monnet \& Cherry 2002), with females reaching maturity at a higher age than males, as was the case in our data for $A$. muletensis. This age-specific sexual size dimorphism has frequently been reported among anurans, and is, in general, the result of sexual differences in growth rates (Ma \& Lu 2009 and references therein).

In conclusion, we provided measurements of the mean longevity, growth curves, growth rates and age at maturity for 17 wild populations of Alytes muletensis, which enables demographic comparisons between populations. These findings will be valuable to the recovery plan of this endemic and threatened toad.

Acknowledgements. We thank Joan A. Oliver, $\mathrm{M}^{\mathrm{a}}$. Antònia Vanrell and Joan C. Salom, from the Balearic Environmental Agency for the administrative support which enabled us to conduct our studies with the Balearic midwife toad. We are also grateful to all the people that supported us during fieldwork, particularly Xavier Manzano and Jaume Bonnin.

\section{LITERATURE CITED}

Alcover JA, Mayol J, Jaume D, Alomar G, Jurado J (1984) Biologia i ecologia de les poblacions de Baleaphryne muletensis a la muntanya mallorquina. In: Hemmer $\mathrm{H}$, Alcover JA (eds) Història biològica del ferreret. Monografies científiques 3. Editorial Moll, Palma de Mallorca, p 129-152

Ananjeva NB, Borkin LJ (1979) Ecology and systematic of amphibians and reptiles. Academy of Sciences of the USSR, Zoological Institute, Moscow

Arnold EN (2003) Reptiles and amphibians of Europe. Princeton University Press, Princeton, NJ

Arntzen JW (2000) A growth curve for the newt Triturus cristatus. J Herpetol 34:227-232

Böllet S, Erben RG, Linsenmair KE (1997) Wie zuverlässig ist die skeletochronologische Altersbestimmung bei der Geburtshelferkröte Alytes obstetricans? Mertensiella 7: 315-327

Briggs L (1996) Populationsdynamische Untersuchungen and Rotbauchunken-Populationen mit verschiedenen Landbiotopen. In: Krone A, Kühnel KD (eds) Die Rotbauchunke (Bombina bombina): Ökologie und Bestandssituation. RANA, Natur \& Text, Berlin, Vol 1, p 32-46
Bush SL (1993) Courtship and male parental care in the Majorcan midwife toad, Alytes muletensis. PhD dissertation, University of East Anglia, Norwich

Castanet J (2002) Amphibiens et reptiles non aviens: un matériel de choix en squelettochronologie. Bull Soc Herpetol Fr 103:21-40

Castanet J, Smirina E (1990) Introduction to the skeletochronological method in amphibian and reptiles. Ann Sci Nat Zool 11:191-196

> Cheong S, Daesik P, Ha-Cheol S, Jung Hyun L, Shi-Ryong P (2007) Skeletochronological age determination and comparative demographic analysis of tow populations of the gold-spotted pond frog (Rana chosenica). J Ecol Field Biol 30:57-62

> Cherry MI, Francillon-Vieillot M (1992) Body size, age and reproduction in the leopard toad, Bufo pardalis. J Zool 228:41-50

Cogalniceanu D, Miaud C (2003) Populations age structure and growth in four syntopic amphibian species inhabiting a large river floodplain. Can J Zool 81:1096-1106

Esteban M, Castanet J, Sanchiz B (1998) Inferring age and growth from remains of fossil and predated recent anurans: a test case using skeletochronology. Can J Zool 76: 1689-1695

Fabens AJ (1965) Properties and fitting the von Bertallanfy growth cure. Growth 29:265-289

Frazer NB, Gibbons JW, Greene JL (1990) Exloring Faben's growth interval model with data on a long-lived vertebrate, Trachemys scripta (Reptilia: Testudinata). Copeia 1990:112-118

González-Miras E, García-Cardenete L, Tejedo M (2012) Historia natural. In: Bosch J, González-Miras E (2012) Seguimiento de Alytes dickhilleni: informe final. Monografías SARE 02. Asociación Herpetológica Española, Ministerio de Agricultura, Alimentación y Medio Ambiente, Madrid, p 17-22

- Guarino FM, Lunardi S, Carlomagno M, Mazzotti S (2003) A skeletochronological study of growth, longevity and age at sexual maturity in a population of Rana latastei (Amphibia, Anura). J Biosci 28:775-782

> Guarino FM, de Pous P, Crottini A, Mezzasalma M, Andreone F (2011) Age structure and growth in a population of Pelobates varaldii (Anura, Pelobatidae) from northwestern Morocco. Amphib-Reptilia 32:550-556

Halliday TR, Tejedo M (1995) Intrasexual selection and alternative mating behavior. In: Heatwole $\mathrm{H}$, Sullivan BK (eds) Amphibian biology. Surrey Beatty and Sons, Chipping Norton, p 419-468

Halliday TR, Verrell PA (1988) Body size and age in amphibians and reptiles. J Herpetol 22:253-265

IUCN (2013) IUCN Red List of Threatened Species. Version 2013.2. www.iucnredlist.org (accessed 16 December 2013)

Jakob C, Miaud C, Crivelli AJ, Veith M (2003) How to cope with periods of drought? Age at maturity, longevity and growth of marbled newts (Triturus marmoratus) in Mediterranean temporary ponds. Can J Zool 81:1905-1911

Knoepffler LP (1962) Contributions a l'étude du genre Discoglossus (Amphibiens, Anoures). Vie Milieu 13:1-94

> Kyriakopoulou-Sklavounou P, Stylianou P, Tsiora A (2008) A skeletochronological study of age, growth and longevity in a population of the frog Rana ridibunda from southern Europe. Zoology 111:30-36

Lande R (1988) Genetics and demography in biological conservation. Science 241:1455-1460 
Leclair R, Laurin G (1996) Growth and body size in population of mink frogs Rana septentrionalis from two latitudes. Ecography 19:296-304

Ma X, Lu X (2009) Sexual size dimorphism in relation to age and growth based on skeleotchronological analysis in a Tibetan frog. Amphib-Reptilia 30:351-359

Márquez R, Esteban M, Castanet J (1997) Sexual size dimorphism and age in the midwife toads Alytes obstetricans and A. cisternasii. J Herpetol 31:52-59

Martins F, Souza FL (2008) Estimates of growth of the Atlantic rain forest freshwater turtle Hydromedusa maximiliani (Chelidae). J Herpetol 42:54-60

Matthews KR, Miaud C (2007) A skeletochronological study of the age structure, growth, and longevity of the mountain yellow-legged frog, Rana muscosa, in the Sierra Nevada, California. Copeia 986-993

Miaud C, Guyétant R, Elmberg J (1999) Variations in lifehistory traits in the common frog Rana temporaria (Amphibia: Anura): a literature review and new data from the French Alps. J Zool 249:61-73

Monnet JM, Cherry MI (2002) Sexual size dimorphism in anurans. Proc Biol Sci 269:2301-2307

Pinya S, Pérez-Mellado V (2009) Individual identification and sexual dimorphism in the endangered Balearic midwife toad, Alytes muletensis (Sanchíz and Adrover, 1981). Amphib-Reptilia 30:439-443

Editorial responsibility: Michael Mahony, Callaghan, Australia
Plytycz B, Bigaj J (1984) Preliminary studies on the growth and movements of the yellow-bellied toad, Bombina variegata (Anura: Discoglossidae). Amphib-Reptilia 5: 81-86

Román A (2002) Alytes muletensis. In: Pleguezuelos JM, Márquez R, Lizana M (eds) Atlas y libro rojo de los anfibios y reptiles de España. Dirección General de Conservación de la Naturaleza and Asociación Herpetológica Española, Madrid, p 79-81

Román A, Mayol J (1997) La recuperación del ferreret, Alytes muletensis. Documents tècnics de Conservació 1. Conselleria de Medi Ambient, Ordenació del Territori i Litoral, Palma de Mallorca

Spencer RJ (2002) Growth patterns of two widely distributed freshwater turtles and a comparison of common methods used to estimate age. Aust J Zool 50:477-490

Sy T, Grosse WR (1998) Populationsökologische Langzeitstudien an Gelbbauchunken (Bombina v. variegata) im nordwestlichen Thüringen. Z Feldherpetol 5:81-113

Yilmaz N, Kutrup B, Çobanoglu U, Özoran Y (2005) Age determination and some growth parameters of a Rana ridibunda population in Turkey. Acta Zool Acad Sci Hung 51:67-74

Zug RG, Kalab J, Luzar J (1997) Age and growth in wild Kemp's ridley seaturtles Lepidochelys kempii from skeletocronological data. Biol Conserv 80:261-268

Submitted: February 14, 2013; Accepted: October 2, 2013 Proofs received from author(s): December 17, 2013 